\title{
ПАТОГЕНЕТИЧНІ МЕХАНІЗМИ ФОРМУВАННЯ ПОСТСТРЕСОВОЇ ПСИХОЛОГІЧНОЇ ДЕЗАДАПТАЦІЇ У СПІВРОБІТНИКІВ МВС УКРАЇНИ ПІСЛЯ УЧАСТІ В АТО
}

УДК: $159.9 .07 ; 159.9 .07:: 51-7$

\begin{abstract}
Козира П. В.
Психолог на волонтерських засадах Обласного комунального закладу Львівської обласної ради «Львівський обласний державний клінічний наркологічний диспансер», старший інспектор з озброєння Львівського державного університету внутрішніх справ, м. Львів (Україна)
\end{abstract}

\begin{abstract}
Анотація. Проведене дослідження спрямоване на розробку моделі патогенетичних механізмів розвитку постстресової психологічної дезадаптації у співробітників МВС Украӥни після участі в АТО.

Автором встановлено емоційно-афективний та психопатоподібний варіанти постстресової психологічної дезадаптаиії в службовичів МВД України, щчо приймали участь в АТО, які різняться між собою рівнем $і$ якістю дезадаптативних проявів. Постстресова психологічна дезадаптація складається з двох структур, які мають різне походження та грають різні ролі в формуванні дезадаптації. Це структура нових поведінкових стратегій $i$ власне посттравматичні порушення. Кожній встановленій структурі відповідно варіанту дезадаптації характерні відповідні зміни в поведінковій, емоційній та когнітивній сферах особистості. Витоки встановлених варіантів дезадаптації знаходяться в особливостях виховання та набутого життєвого досвіду.

На основі запропонованої моделі патогенетичних механізмів, автором запропоновано створення диференційованої системи психокорекції різних варіантів постстресової психологічної дезадаптаиії у учасників АТО.
\end{abstract}

Ключові слова: Психологічна дезадаптація, патерни поведінки, посттравматична дезадаптація, патогенетичні механізми, психодіагностика.

Постановка проблеми. Значні політичні, суспільні, економічні зміни на Україні, які виходять за рамки звичайного досвіду та наближаються до перманентного характеру не можуть не позначатися на стані психічного здоров'я населення $[1,2]$. Ці події призводять до розвитку соціально-стресових розладів, а участь населення в бойових діях - до розвитку у їх учасників посттравматичного стресорного розладу (ПТРС) [2, 3, 4]. В порівнянні з ними 
доклінічні порушення у вигляді постстресової психологічної дезадаптації зачіпають значно більшу кількість населення, особливо співробітників МВС України. Останні безпосередньо приймають участь в цих подіях та відчувають на собі всі їх наслідки $[4,5,6]$. Вони використовуються тієї чи іншою протиборчою стороною суспільства у їх протистоянні; міняються сутності розпоряджень та ступінь навантаження на їх служби. Змінюються ролі служби в суспільстві, відношення до них населення та влади, співробітники приймають участь в боях $з$ мешканцями цієї ж країни. Ступінь дезадаптації особистості в наслідок стресорного впливу та рівень дістресу залежать від багатьох чинників, включаючи особливості та риси іiі характеру [7]. Особливо важливим є розуміння взаємодії і ролі цих факторів в формуванні патогенетичних механізмів постстресової дезадаптації для ії корекції, прогнозування та профілактики [8].

Мета дослідження. Метою дійсного дослідження $є$ розробка моделі патогенетичних механізмів розвитку постстресової психологічної дезадаптації у співробітників МВС України після участі в АТО.

Матеріали та методи дослідження. Було проведено клініко-психологічне і психодіагностичне обстеження психологічного стану 205 співробітників МВС України віком 2937 років, які знаходились на службі не менше як з 2010 року. 3 них 148 брали участь в проведенні АТО протягом 2014-15 років (досліджувана група); 57 - не брали участі в ATO (група порівняння). В дослідженні були застосовані методики:

Опитувальник виразності психопатологічної симптоматики (SCL-90-R) Дерогатіс,

Багаторівневий особистісний опитувальник «Адаптивність» (МЛО-АМ),

Клінічний опитувальник для виявлення і оцінки невротичних станів (К.К.Яхин, Д.М.Менделевич),

«Психологічний захист» Плутчика - Келлермана - Конте»,

Визначення схильності до відхиляючої поведінки (А.Н.Орел),

Діагностика рівня соціальної фрустрованості Л.І. Вассермана,

Біографічний опитувальник (Bottscher, Jager, Lischer),

Шкала оцінки впливу травмуючої події (IMPACT OF EVENT SCALE-R-1ES-R), Діагностика копінг-стратегій Хайма,

«Психологічна автобіографія» (Л.Ф. Бурлачук, Е.Ю. Коржова)

Гісенський опитувальник психосоматичних скарг,

Тест життєстійкості в адаптації Д.О. Леонтьєва, О.І. Рассказової,

Опитувальник проактивної подолаючої поведінки,

Опитувальник посттравматичного зростання.

Результати оброблялись методами статистичного та факторного аналізу методом головних компонент. Критерій адекватності 
вибірки Кайзера-Мейера-Олкіна, що характеризує ступінь застосовності факторного аналізу для вибірки склав 0.62. Критерій сферичності Барлетта показав рівень значимості $\mathrm{p}$ $<0,01$.

Результати дослідження. В результаті дослідження у службовців МВС України, які приймали участь в АТО, в 89,86\% виявлені, різні за виразністю, дезадаптивні прояви. У 8,78\% випадків симптоми досягали клінічного рангу, але були недостатніми для виставлення клінічно окресленої нозологічної форми порушень. Встановлена наявність доклінічних порушень з боку емоціональної, когнітивної та поведінкової сфер особистості. На підставі аналізу феноменології встановлено 2 варіанти перебігу психологічної постстресової дезадаптації: емоційно-афективний варіант постстресової психологічної дезадаптації (ЕАВПД), що характеризується переважаючими проявами з боку емоційної сфери та психопатоподібний варіант постстресової психологічної дезадаптації (ППВПД), для якого характерні переважно поведінкові, когнітивні прояви та невротичні включення на тлі емоційних скарг. Виявлений дисонанс оцінки дезадаптивних проявів самими учасниками АТО та їх оточенням. Поведінкові прояви та особливості реагування учасники АТО розцінювали як позитивні набуті якості, що допомагають їм у мирному житті, тоді як оточуючі негативно оцінюють набуті зміни.

Структурі ЕАВПД притаманні напру- ження відносин сім'ї з суспільством, висока інтенсивність емоційних проявів та їх лабільність, утруднення підтримки контактів та схильність до дезадаптації на тлі явищ екстраверсії. Результати впливу психотравмуючої ситуації достовірно більш високі по шкалі «вторгнення» та «фізіологічного збудження». Серед способів психологічного захисту група відрізнялась достовірно більшою напругою лише за шкалою «заміщення». При ППВПД емоційні особливості індивідуального розвитку особистості представлені показниками сімейного дефіциту, низької сили «Я» та зниження впевненості в собі, високої схильністю до соматичних реакцій на тлі низького спротиву стресу, напруги у відносинах з близькими та суспільством. На вплив стресорного чинника в групі переважає реакція «уникнення». 3 психологічного захисту напруга більш висока по шкалах «витіснення», «регресії» та «заміщення», а по шкалі «компенсації» - низька.

При порівняння результатів дослідження прослідковується зв'язок між клінічними проявами варіантів дезадаптації, локусами фрустрації, соціальним та сімейним оточенням, результатами впливу травматичної події та способами психологічного захисту. На тлі виявлених змін вивчення використовуваних учасниками копінг-стратегій показало, що найменш адаптованою є група з ППВПД. Група з ЕАВПД $є$ більш адаптована. Найбільш адаптованими були співробітники гру- 
пи контролю, які не використовували жодної із стратегії, що притаманні учасникам АТО.

Дослідження виразності психопатологічної симптоматики є важливим з точки зору іiі наявності та інтенсивності. Показники виразності психопатологічної симптоматики опитувальника Дерогатіс при ППВПД учасників АТО рівень дістресу та важкість симптоматики більш виражені, ніж при ЕАВПД. Ця різниця була достовірна, або проявляла тенденцію майже за всіма шкалами. Виключенням була шкала «ворожості», рівень якої був вищий в групі 1. Останнє узгоджується 3 встановленим раніше фактом більш агресивної поведінки учасників цієї групи.

Показники адаптивності учасників АТО результатами опитувальника «Адаптивність» по всіх застосованих шкалах в обох варіантах дезадаптації достовірно перевищували такі для групи порівняння. При порівнянні між встановленими варіантами дезадаптації більш виражений рівень порушень встановлено при ППВПД.

Результати дослідження проактивної долаючої поведінки, які застосовувались учасниками дослідження в умовах стресу свідчать, що учасники групи 1 більш схильні до прогнозування можливих стресів та підготовки ресурсів для їх подолання. При цьому використовують пошук необхідних ресурсів та емоційної підтримки з боку оточення. Така поведінка в комплексі з раніш представленими їх особливостями робить їх досить успішними, активними, досить агресивними особами, які знають свою мету і прикладають максимум зусиль для швидкого її досягнення.

При ППВПД учасники характеризувалися прогнозуванням можливих стресів та підготовки ресурсів для їх подолання разом із розробкою, плануванням альтернативних шляхів вирішення проблем в перспективі. При цьому вони не шукають активно підтримку та ресурси в своєму оточенні, більше розраховують на свої сили та уміння. Така поведінка в комплексі з раніш представленими їх особливостями робить їх досить наполегливими, 3 використанням своїх заслуг та жертв для досягнення матеріальних, соціальних пільг та преференцій. Вони також в тій чи іншій мірі можуть спрямовувати свою активність на різні сфери суспільного життя, але більш за все в ті, в яких вони особисто заінтересовані.

Важливим є характеристика стійкості особистості до стресорного впливу та подолання стресу. Рівні життєстійкості в групі 3 ЕАВПД були достовірно підвищені, а 3 ППВПД - знижені. Це свідчить про те, що ЕАВПД проявляє значно більш високу стійкість до стресорного впливу, а засвоєні нові способи поведінки та реагування використовуються особистістю для подальшої своєї діяльності без значної шкоди для себе. При ППВПД зниження життєстійкості свідчить про виснаження ресурсів особистості i ïx спрямованість лише на захист своїх інтересів та компенсацію втрат. 
Важливим показником є оцінка особистості стресорного впливу на іiі якості, що дає дослідження посттравматичного зростання. В порівнянні між групами достовірно більш виражені зміни виявлені при ЕАВПД. Відмінності відсутні лише по шкалам «духовні цінності» та «збільшення цінності життя». Результати підтверджують данні інших методик та опитування, які вказують на позитивну оцінку набутих якостей та поведінки особистістю під час участі в АТО та застосування їх у мирному житті. Посттравматичний ріст як сума шкал при цьому варіанті дезадаптації майже в 2 рази перевищував аналогічний показник для групи 2. При ППВПД нтів дезадаптації, так і всередині кожного 3 варіантів. Якщо різниця між обома варіантами дезадаптації була досить пояснювана та зрозуміла, то в характеристиках кожного 3 варіантів потребувала пояснення. Виходячи 3 цього факту нами була висунута гіпотеза про різне походження виявлених змін, що характерні для постстресової психологічної дезадаптації. Для верифікації гіпотези було проведено факторний аналіз методом головних компонент одержаних результатів проведеного дослідження. Критерій адекватності вибірки Кайзера-Мейера-Олкіна, що характеризує ступінь застосовності факторного аналізу для цієї вибірки склав 0.62. Критерій сферичності БарТаблиия 1

\section{Факторна структура аналізу постстресової психологічної дезадаптації}

\begin{tabular}{|l|l|c|}
\hline $\begin{array}{l}\text { No } \\
\text { 3п }\end{array}$ & \multicolumn{1}{|c|}{ Фактор } & $\begin{array}{c}\text { Факторне нава- } \\
\text { нтаження }\end{array}$ \\
\hline 1. & Нові поведінкові стратегії при ЕАВПД & 25,323 \\
\hline 2. & Посттравматичні порушення при ППВПД & 23,157 \\
\hline $3 \cdot$ & Посттравматичні порушення при ЕАВПД & 19,461 \\
\hline $4 \cdot$ & Нові поведінкові стратегії при ППВПД & 16,526 \\
\hline
\end{tabular}

як самі показники росту, так і оцінки змін 3 боку учасників значно стриманіші. Це ще $\epsilon$ одним доказом менш вираженої дезадаптації учасників АТО з ЕАВПД.

Аналізуючи всі сукупні матеріали, ми звернули увагу на наявність як спряжених, так i різно направлених результатів. Такі явища були характерні як при порівнянні обох варіа- летта показав рівень значимості $<0.01$. В результаті було виявлена факторна структура, яка складалася із 6-х факторів. До аналізу були прийняті 4 фактори (табл. 1). Інші два були проігноровані у зв'язку з мінімальними показниками їх факторного навантаження. Після аналізу ознак, які входили до складу факторів, останнім була присвоєна назва, яка відобра- 
жала сутність кожного фактору.

Для факторів «Нові поведінкові стратегії при ЕАВПД» та «Нові поведінкові стратегії при ППВПД» були характерні ознаки які представляли копінг-стратегії, психологічний захист, схильність до відхиляючої та варіанти подолаючої поведінки, рівні життєстійкості, особливості впливу травмуючої події та характеристики посттравматичного зростання, шкалам біографічного опитувальника, джерела та інтенсивність фрустрації та результати психологічної автобіографії. Рівні цих ознак відповідали вказаним варіантам психологічної дезадаптації.

$$
\text { В структуру факторів }
$$

«Посттравматичні порушення при ППВПД» i «Посттравматичні порушення при ЕАВПД» входили ознаки, що характеризували рівні та актуальність скарг, виразність психопатологічної симптоматики, рівень психосоматичних скарг, адаптивність та рівні стресу, виявлення і оцінку невротичних станів, данні шкал біографічного опитувальника, рівень життєстійкості та характер посттравматичного зростання, показники шкал біографічного опитувальника та результати психологічної автобіографії.

Таким чином, факторний аналіз виявив спряженість та зняв уявні протиріччя в одержаних результатах. Виявлені фактори та групування їх ознак підтвердили гіпотезу про різне походження виявлених відхилень. Першою структурою, яка продукує явища психологічної дезадаптації є набуті під час участі в
АТО нові поведінкові стратегії (патерни). Зважаючи на те, що навчання та засвоєння нових поведінкових стратегій проходило в умовах перманентного психологічного і соматичного стресу, наявності реальної вітальної загрози та відповідало новим умовам життєдіяльності особистості, ці стратегії носять актуальний, 3 високим рівнем емоційно-афективного супроводу, характер. Вони підтверджені успішним досвідом їх застосування в умовах бойових дій та дозволили особистості успішно функціонувати та вижити в цих умовах. Можна сказати, що в результаті участі в АТО особистість набула, актуального для неї, досвіду та одержала додаткові інструменти для більш успішної життєдіяльності. І це має однозначну позитивну оцінку учасників з обома варіантами дезадаптації.

Але застосування у мирному житті поведінкових патернів, набутих і ефективних в умовах бойових дій, призводить до виникнення конфліктних ситуацій в суспільному та особистому житті, професійній діяльності. 3 одного боку, особистість знає про ефективність такої поведінки, а з іншого - іiі застосування призводить до конфлікту. Крім того, нові поведінкові патерни формують дисоціативні процеси у міжособистісних відносинах в сім'ї, близькому оточенні, професійній діяльності. Це пов'язане з новою, незнайомою для оточуючих, поведінкою та системою цінностей і пріоритетів у життєдіяльності учасників АТО в умовах мирного життя. Формуються 
стресорні відносини в різних серах життя, які носять характер фрустрації. Таким чином формується стан психологічної дезадаптації.

Два інших фактори, по сукупності своїх ознак, представляють власне психологічну дисфункцію як реакцію на перманентний стресорний стан з ознаками вітальної загрози при участі в АТО. Різниця між встановленими варіантами дезадаптації зводиться до різниці в рівнях, спектру, значимості та характеру проявів дезадаптації. Для ППВПД характерно більш виражений та важчий перебіг порушень, ніж при ЕАВПД.

При порівнянні структури ознак одержаних факторів виявлено, що для кожного варіанту посттравматичного порушення до структури ознак входять результати аналізу біографічних даних, копінг-стратегій, актуальність та значимість симптоматики (проявів). Більш детальне додаткове дослідження показало, що нові поведінкові патерни розцінюються учасниками АТО як позитивні для них, зміни. На відміну від оточуючих людей, які оцінювали їх як негативні. Такий дисонанс в оцінках особливо виразний в виявлених локусах фрустрації особистості учасника. При ЕАВПД явище відносилось переважно до суспільної сфери, професійної діяльності та особистого життя. При цьому, особистісна зацікавленість та залежність учасника біла досить слабкою і ці локуси можна віднести до суспільної діяльності. Для ППВПД при наявності позитивної оцінки набутих патернів, локуси фрустрації носили яскраву особистісну залежність та зацікавленість. Набуті патерни поведінки широко та інтенсивно використовувались для вирушення проблем особистісного характеру. При порівнянні обох варіантів дезадаптації, прояви власне постстресорних порушень при ЕАВПД применшувались або ігнорувались, а при ППВПД - перебільшувались та акцентувались.

Додаткове порівняння значущості біографічних подій учасниками АТО виявило зміну їх оцінки. Так при ЕАВПД збільшувалась кількість та оцінка значущості суспільних подій і зменшувалась подій особистісного характеру у минулому. У майбутньому вага та значущість прогнозованих подій також значно відрізнялись. При ППВПД переоцінка торкалась подій як в минулому, так і в майбутньому і відносились вони до особистісного життя.

Такі встановлені додаткові характеристики дозволили стверджувати, що при ЕАВПД зміни особистості носять переважно суспільно та соціально спрямований характер, а при ППВПД - переважно особистісно спрямований. Витоки такої перебудови стратегії поведінки особистості з набутими новими патернами поведінки при участі в АТО слід шукати в особливостях виховання та набутого життєвого досвіду.

\section{Висновки.}

1. Встановлені емоційно-афективний та психопатоподібний варіанти постстресової психологічної дезадаптації в службовців МВД 
України, що приймали участь в АТО, які різняться між собою рівнем і якістю дезадаптативних проявів.

2. Постстресова психологічна дезадаптація складається 3 двох структур, які мають різне походження та грають різні ролі в формуванні дезадаптації. Це структура нових поведінкових стратегій і власне посттравматичні порушення.

3. Кожній встановленій структурі відповідно варіанту дезадаптації характерні відповідні зміни в поведінковій, емоційній та когнітивній сферах особистості. Витоки встановлених варіантів дезадаптації знаходяться в особливостях виховання та набутого життєвого досвіду.

\section{Перспективою подальших дослі-} джень $є$ розробка, на основі запропонованої моделі патогенетичних механізмів, диференційованої системи психокорекції різних варіантів постстресової психологічної дезадаптації у учасників АТО.

\section{Перелік використаних джерел:}

1.Кровяков В. М. Психотравматология. Психическая травма, психогении в этиопатогенетических механизмах развития психических расстройств. - М.: Наука, 2005. - 379 c.

2. Близнюк А. И. Посттравматическое стрессовое расстройство (ПТСР) у комбатантов, клиника, диагностика, коррекция / А.И. Близнюк /Военно-медицинский журнал, №1, БГМУ, Минск, 2005г. - С. 1-14.

3. Психиатрия войн и катастроф / ред. В. К. Шамрей. СПб.: СпецЛит, 2015. - 620 с.
4. Корнієнко I. О. Копінг-поведінка сім'ї як предмет психологічного дослідження/ I. О. Корнієнко/ Проблеми сучасної психології, Вип. 20, 2013. - с.73-283.

5. Исаева E. P. Копинг-поведение и психологическая защита личности в условиях здоровья и болезни //СПб.: Изд-во СПбГМУ. - 2009. - Т. 136. - с.40-46.

6. Бугайова H. М. Адаптивний потенціал людини та стресова резистентність: синергетичний контекст // Збірник наукових праць Інституту психології імені Г.С. Костюка Національної АПН України. Проблеми загальної та педагогічної психології. - 2012. - №. 24, ч. 5. - С. $33-41$.

7. Леонтьев Д. А. Многоуровневая модель взаимодействия с неблагоприятными обстоятельствами: от защиты к изменению // Психология стресса и совладания: материалы III Междунар. науч.-практ. конф. Кострома, 26-28 сент. 2013 г. В 2 тт. Т. 1 / отв. ред. Т.Л. Крюкова, Е.В. Куфтяк, М.В. Сапоровская, С.А. Хазова. - Кострома : КГУ им. Н.А. Некрасова, 2013. - С. 258-261.

8. Малкіна-Пих І. Г. Психологічна допомога в кризових ситуаціях - М.: Изд-во Ексмо. - 2005. - 960 с.

\section{References (Transliteration):}

1. Krovyakov V. M. Psikhotravmatologiya. Psikhicheskaya travma. psikhogenii $\mathrm{v}$ etiopatogeneticheskikh mekhanizmakh razvitiya psikhicheskikh rasstroystv. - M.: Nauka. 2005. - 379 s.

2. Bliznyuk A. I. Posttravmaticheskoye stressovoye rasstroystvo (PTSR) u kombatantov. klinika. diagnostika. korrektsiya / A.I. Bliznyuk /Voyenno-meditsinskiy zhurnal. №1. BGMU. Minsk. 2005g. - S. 1-14.

3.Psikhiatriya voyn i katastrof/ red. V. K. Shamrey. - SPb.: SpetsLit. 2015. - $620 \mathrm{~s}$.

4. Kornienko I. O. Koping-povedinka sim’ï yak predmet psikhologichnogo doslidzhennya/ I. O. Kornienko/ Problemi suchasnoï psikhologiï. Vip. 20. 2013. - s.73-283. 
5. Isayeva E. R. Koping-povedeniye i psikhologicheskaya zashchita lichnosti v usloviyakh zdorovia i bolezni //SPb.: Izd-vo SPbGMU. - 2009. - T. 136. - s.40-46.

6. Bugayova N. M. Adaptivniy potentsial lyudini ta stresova rezistentnist: sinergetichniy kontekst //Zbirnik naukovikh prats Institutu psikhologii imeni G.S. Kostyuka Natsionalnoï APN Ukraini. Problemi zagalnoï ta pedagogichnoi psikhologii. - 2012. - №. 24. ch. 5. - S. 33-41.

7. Leontyev D. A. Mnogourovnevaya model vzaimodeystviya s neblagopriyatnymi obstoyatelstvami: ot zashchity k izmeneniyu // Psikhologiya stressa i sovladaniya: materialy III Mezhdunar. nauch.-prakt. konf. Kostroma. 2628 sent. 2013 g. V 2 tt. T. 1 / otv. red. T.L. Kryukova. E.V. Kuftyak. M.V. Saporovskaya. S.A. Khazova. - Kostroma : KGU im. N.A. Nekrasova. 2013. - S. 258-261.

8. Malkina-Pikh I. G. Psikhologichna dopomoga v krizovikh situatsiyakh - M.: Izd-vo Eksmo. - 2005. - 960 s.

\section{Kozira Piotr}

Psychologist at Lviv regional municipal institution "Lviv Regional State Clinical Drug Treatment Centre", senior inspector of arms of Lviv State University of Internal Affairs, Lviv (Ukraine)

\section{PATHOGENETIC MECHANISMS OF AFTER STRESS PSYCHOLOGICAL MALADJUSTMENT OF POLICEMAN'S AFTER PARTICIPATION IN THE ANTI -TERRORIST OPERATION}

\section{ABSTRACT}

Employees of the Interior Ministry of Ukraine in conditions of permanent the Political, economic and social changes of the fighting are directly involved in them and suffer the consequences of all these events in the form of poststress psychological maladjustment. The degree of personality maladjustment due to the effects of stress and the level of distress depends on many factors, including the characteristics and traits. Especially important is the understanding of the interaction and the role of these factors in the formation of pathogenic mechanisms poststress maladjustment for its subsequent correction, forecasting and prevention.

Purpose of the study. The aim of this study is to develop a model of pathogenetic mechanisms of development of poststress of psychological maladjustment XYZ employees of MIA of Ukraine after participating in the ATO.

Materials and methods. It was conducted clinical and psychological examination of psychodiagnostic and psychological state of the 205 employees of MIA of Ukraine. Of these, 148 participated in the conduct of the ATO. The results were processed using principal components factor analysis method. Criterion sampling adequacy Kaiser-Meyer-Olkina for the sample was 0.62. The criterion of sphericity showed Barletta significance level $<0.01$.

Results of the study. Establishing an emotional-affective and psychopathic options poststress psychological maladjustment among employees of MIA of Ukraine, took part in the ATO, which differ in the level and quality of disadaptation manifestations. Poststress psychological maladjustment consists of two entities with different origins and playing different roles in the formation of maladjustment. This structure of the new behavioral strategies and proper posttraumatic disorders. Each fixed structure, respec- 
tively variant maladjustment characterized by corresponding changes in the behavioral, emotional and cognitive areas of personality. The origins of maladjustment installed options are especially education and life experience.

Prospects for further research is to develop on the basis of the proposed model of pathogenetic mechanisms, differentiated system psychocorrection different options poststress psychological maladjustment participants ATO.

Keywords: psychological maladjustment, patterns of behavior, post-traumatic exclusion, pathogenetic mechanisms, psychological diagnostics.

\section{Козира Пётр Владимирович}

Психолог на волонтерских началах Областного коммунального учреждения Львовского областного совета "Львовский областной государственньй клинический наркологический диспансер", старший инспектор по вооружению Львовского государственного университета внутренних дел, г. Львов (Украина)

\section{ПАТОГЕНЕТИЧЕСКИЕ МЕХАНИЗМЫ ФОРМИРОВАНИЯ ПОСТ СТРЕССОВОЙ ПСИХОЛОГИЧЕСКОЙ ДЕЗАДАПТАЦИИ У СОТРУДНИКОВ МИНИСТЕРСТВА ВНУТРЕННИХ ДЕЛ ПОСЛЕ УЧАСТИЯ В АНТИ-ТЕРРОРИСТИЧЕСКОЙ ОПЕРА- цИИ}

Аннотация. Сотрудники МВД Украины в условиях перманентных политических, экономических и социальных изменений, проведения боевых действий принимают непосредственное участие в них и испытывают на себе все последствия этих событий в виде постстрессовой психологической дезадаптации.
Степень дезадаптации личности вследствие стрессорного воздействия и уровень дистресса зависят от многих факторов, включая особенности и черты характера. Особенно важным является понимание взаимодействия и роли этих факторов в формировании патогенетических механизмов постстрессовой дезадаптации для последующей ее коррекции, прогнозирования и профилактики.

Цель исследования. Целью настоящего исследования является разработка модели патогенетических механизмов развития постстрессовой психологической дезадаптации у сотрудников МВД Украины после участия в ATO.

Материалы и методы исследования. Было проведено клинико-психологическое и психодиагностическое обследование психологического состояния 205 сотрудников МВД Украины. Из них 148 участвовали в проведении АТО. Результаты обрабатывались с использованием факторного анализа методом главных компонент. Критерий адекватности выборки Кайзера-Мейера-Олкина для выборки составил 0.62. Критерий сферичности Барлетта показал уровень значимости $<0.01$.

Результаты исследования. Установлены эмоционально-аффективный и психопатоподобный варианты постстрессовой психологической дезадаптации у служащих МВД Украины, принимавших участие в АТО, которые различаются между собой уровнем и качеством дезадаптационных проявлений. Пост- 
стрессовая психологическая дезадаптация состоит из двух структур, имеющих различное происхождение и играющих разные роли в формировании дезадаптации. Это структура новых поведенческих стратегий и собственно посттравматические нарушения. Каждой установленной структуре соответственно варианта дезадаптации характерны соответствующие изменения в поведенческой, эмоциональной и когнитивной сферах личности. Истоки установленных вариантов дезадаптации находятся в особенностях воспитания и приобретенного жизненного опыта. Перспективой дальнейших исследований является разработка на основе предложенной модели патогенетических механизмов, дифференцированной системы психокоррекции различных вариантов постстрессорной психологической дезадаптации у участников АТО.

Ключевые слова: Психологическая дезадаптация, паттерны поведения, посттравматическая дезадаптация, патогенетические механизмы, психодиагностика. 